EDUKACJA MIĘDZYKULTUROWA

2018, nr 1 (8)

ISSN 2299-4106

DOI: $10.15804 / \mathrm{em} .2018 .01 .21$

\title{
Prace z edukacji wielo- i międzykulturowej wydane w roku 2017
}

Badowska M.: Ku integracji społecznej: studium pedagogiczne. Pułtusk - Warszawa 2017, Akademia Humanistyczna im. Aleksandra Gieysztora, Oficyna Wydawnicza Aspra-JR.

Błeszyńska K.M. (red.): Edukacja międzykulturowa jako czynnik rozwoju kultury pokoju. Gdańsk 2017, Wydawnictwo Naukowe Katedra.

Budrewicz Z., Sienko M. (red.): Inny w edukacji i kulturze regionu. Kraków 2017, Wydawnictwo Naukowe Uniwersytetu Pedagogicznego.

Chudzio H., Kolenda Z., Kulpińska J. (red.): Nowoczesne nauczanie tradycji ojczystych - Sybiracy i młodzież. Kraków 2017, Wydawnictwo Polskiej Akademii Umiejętności.

Djuliman E., Hjorth L.: Edukacja międzykulturowa na rzecz zrównoważonego rozwoju. Buduj mosty nie mury: 97 ćwiczeń z zakresu praw człowieka, zrozumienia interkulturowego i rozwiq̨zywania konfliktów. Warszawa 2017, Wydawnictwo Akademickie „Dialog” Anna Parzymies.

Duda A.K., Łukasik J.M. (red.): Polsko-rosyjskie kolaże: edukacja, społeczeństwo, kultura. Kraków 2017, Uniwersytet Pedagogiczny im. Komisji Edukacji Narodowej.

„Edukacja Międzykulturowa” 2017, nr 1 (6).

„Edukacja Międzykulturowa” 2017, nr 2 (7).

Gajdzica A., Piechaczek-Ogierman G., Hruzd-Matuszczyk A.: Edukacja postrzegana z perspektywy uczniów, rodziców i nauczycieli ze szkół z polskim językiem nauczania w wybranych krajach europejskich. Torun 2017, Wydawnictwo Adam Marszałek (II wydanie).

Garbula J.M., Jacek Jan Pawlik J.J. (red.): Religia i edukacja w styczności z różnorodnościa kulturowa. Olsztyn 2017, Wydawnictwo Uniwersytetu Warmińsko-Mazurskiego.

Guziuk-Tkacz M., Matyjewicz M., Siegień-Matyjewicz A.J. (red.): Oblicza etnopedagogiki i transkulturowości: dyskursy teorii i praktyki edukacyjnej. Olsztyn 2017, Wydawnictwo Uniwersytetu Warmińsko-Mazurskiego. 
Januszewska E., Markowska-Manista U.: Dziecko „inne” kulturowo w Polsce: $z$ badań nad edukacją szkolnq. Warszawa 2017, Wydawnictwo Akademii Pedagogiki Specjalnej.

Jasiński Z., Neisch K., Pogorzelska M. (red.): Oświata i kultura w wielokulturowym świecie - wielość perspektyw i doświadczeń. Opole 2017, Wydawnictwo Uniwersytetu Opolskiego.

Kania A.: Lekcja (nie)obecności: dziedzictwo polsko-żydowskie w edukacji polonistycznej. Kraków 2017, Towarzystwo Autorów i Wydawców Prac Naukowych Universitas.

„Kultura i Edukacja” 2017, nr 4 (118).

Liebel M., Markowska-Manista U.: Prawa dziecka $w$ kontekście międzykulturowości. Janusz Korczak na nowo odczytany. Warszawa 2017, Wydawnictwo Akademii Pedagogiki Specjalnej, Polsko-Niemiecka Fundacja na rzecz Nauki.

Lewowicki T., Chojnacka-Synaszko B., Kwadrans Ł., Suchodolska J.: Sfery $\dot{z}$ ycia duchowego dzieci i młodzieży - studium z pogranicza polsko-czeskiego. T. 3. Spostrzeganie wyznaczników tożsamości i postawy wobec Innych. Toruń, 2017, Wydział Etnologii i Nauk o Edukacji Uniwersytetu Śląskiego, Wydawnictwo Adam Marszałek.

Lewowicki T., Szczurek-Boruta A., Szafrańska A.: Sfery życia duchowego dzieci, młodzieży i dorostych - studium z pogranicza polsko-czeskiego. T. 4. O nauczycielach, ich spostrzeganiu świata społecznego i aktywności. Toruń 2017, Wydział Etnologii i Nauk o Edukacji Uniwersytetu Śląskiego, Wydawnictwo Adam Marszałek.

Nilsson P.: Inny niż wszyscy: opowiadanie o chtopcu, który chce wiedzieć, czy jest normalny. Poznań 2017, Wydawnictwo Zakamarki.

Maresz T., Grysińska-Jarmuła K. (red.): Od konfliktu do wspótistnienia $i$ wspótpracy. T. 2, Sąsiedzi w historiografii, edukacji i kulturze. Bydgoszcz 2017, Wydawnictwo Uniwersytetu Kazimierza Wielkiego.

Nikitorowicz J.: Etnopedagogika w kontekście wielokulturowości i ustawicznie ksztattującej się tożsamości. Kraków 2017, Oficyna Wydawnicza „Impuls”. Ogrodzka-Mazur E., Błahut G. (red.): Pedagogika a etnologia $i$ antropologia kulturowa: wspólne obszary badań. Zwierzęta w kulturze i wychowaniu. Cieszyn - Toruń 2017, Wydział Etnologii i Nauk o Edukacji Uniwersytetu Śląskiego, Wydawnictwo Adam Marszałek.

Prokop D.: Język polski i kultura polska w Chinach. Łódź 2017, Wydawnictwo Primum Verbum. 
Rogalska-Marasińska A.: Edukacja międzykulturowa na rzecz zrównoważonego rozwoju. Łódź 2017, Wydawnictwo Uniwersytetu Łódzkiego.

Żyłkiewicz-Płońska E.: Europejski wymiar w edukacji młodzieży akademickiej. Studium porównawcze. Gdańsk 2017, Wydawnictwo Naukowe Katedra.

Opracowanie

Barbara Grabowska 